\title{
OPINION
}

\section{Citizens (Even) in Prison}

\author{
Antony Duff
}

In nineteen of the states contracted to the European Convention on Human Rights (ECHR), citizens serving terms of imprisonment retain the right to vote; in seven, serving prisoners are barred from voting; in twenty-one, some may lose the right to vote. ${ }^{1}$ In some American states those who serve prison terms for felonies lose the right to vote not only while in prison, but for life. The Netherlands is one of the states that permits selective disenfranchisement of prisoners (a provision that is applied, sparingly, by judges in passing sentence); Britain is one of the states that denies the vote to all prisoners.

In 2005, the European Court of Human Rights (ECtHR) held that Britain's blanket ban on voting for all prisoners constituted a violation of Article 3 of Protocol 1 of the ECHR (the 'Right to Free Elections') - a judgment confirmed in 2012. One might have expected that the British government would therefore legislate without undue delay to remove the blanket ban: if not to allow all prisoners the vote, at least to replace it by a more discriminating ban. But this has not (yet) happened: successive governments have made clear their distaste for the Court's ruling, and their extreme reluctance to allow any prisoners to vote; the legislature has voted decisively against any change in the law. What is most striking about the public debate is not the mere fact that Britain differs from many of its European neighbours, but the strength of feeling (one might almost call it hysteria) aroused by the suggestion that prisoners might be allowed to vote. The Prime Minister, David Cameron, said that it made him 'physically ill even to contem-

1 Human Rights Futures Project, Prisoner Voting and Human Rights in the UK (London: LSE, 2013; available at www.lse.ac.uk/humanRights/articlesAndTranscripts/2013/PrisonerVotes.pdf). Not all who are detained in prison lose the right to vote: those remanded in prison while awaiting trial retain it. The issue concerns those serving prison terms as punishments; in what follows, 'prisoners' refers to convicted offenders serving prison terms.

2 Hirst v. United Kingdom (No. 2) (2006) 42 EHRR 41; Scoppola v. Italy (No. 3) (2012) 56 EHRR 663. But in Scoppola the Court widened the 'margin of appreciation' allowed to states in deciding just how to regulate the issue: individual states that wished to bar some prisoners from voting could decide, consistently with the Convention, whether a ban on voting should be imposed only by the sentencing judge in individual cases, or could be imposed in general terms by statute; and what kinds of crime should attract such a ban. For the Court's recent judgments, see www.echr.coe.int/Documents/FS_Prisoners_vote_ENG.pdf. 
plate having to give the vote to anyone who is in prison, ${ }^{3}$ and his feelings are clearly shared by many in Britain.

Being barred from voting might not rank high on many prisoners' lists of the losses that accompany a prison sentence: for many, it is far outweighed by such other matters as the loss of liberty, of family, of employment, of privacy, and too often of physical and psychological safety. It is, however, something that we should all care strongly about; the Prime Minister was right to care, but shamefully wrong in the direction of his feelings. Citizens of countries that deny their prisoners the right to vote should feel ashamed of their collective failure in this matter: such a denial of the right to vote gives symbolic expression to a deeper, exclusionary attitude towards those who commit crimes serious enough to warrant a prison term (which, in Britain and the USA, need not be terribly serious). Citizens of countries that allow prisoners to vote should resist any move to abolish this mark of democratic inclusiveness; those whose laws allow some prisoners to be deprived of the right to vote should ask themselves why, and for what kinds of offence, any such deprivation can really be warranted.

To clarify the issue here, we can contrast two understandings of the relationship between citizenship and crime - of how a person's commission of a crime bears on his citizenship in the polity by whose laws he is convicted and punished.

(Two preliminaries. I speak of 'he' because the vast majority of imprisoned offenders are male. I speak of 'citizenship', since though many prisoners are not citizens of the country that imprisons them, it is the fate of citizens that concerns me here: questions about the treatment and status of non-citizen offenders are for another occasion.)

On one, exclusionary understanding there is an inconsistency between citizenship and crime: to commit a crime (serious enough to warrant imprisonment) is to deny the bonds of citizenship; to sentence someone convicted of such a crime to imprisonment is to give vivid material form to the exclusion from civic life that he has brought upon himself. On this view, convicted offenders are not, qua convicted offenders, citizens (and so should not be allowed to vote); the civic roles that citizens may play do not include 'convicted offender.' Citizens may play such roles as victim, witness and accused person (who is to be presumed innocent): to acquire such a role, and the distinctive duties and rights that structure it, is to acquire a new civic role, which does not put in doubt or undermine their citizenship. To become a convicted offender, by contrast, is not to acquire a new civic role, with distinctive rights and duties; it is to lose, for a time, one's status as citizen. This conception is often expressed in the language used to describe those

3 Hansard, HC Reports, 3 November 2010, col. 921. Similarly, in 2005 Dominic Grieve (now Attorney General, then shadow Attorney General), said it would be 'ludicrous' to allow prisoners to vote: '[i]f convicted rapists and murderers are given the vote it will bring the law into disrepute and many people will see it as making a mockery of justice' (news.bbc.co.uk/1/hi/uk/ 4315348.stm). 
convicted of serious crimes, as well as in their treatment: they become the dangerous other, the enemies against whom 'we', the law-abiding, must be protected.

On the opposing, inclusionary, understanding, neither the commission of, nor conviction for, a crime puts citizenship in doubt. Committing a crime is not, of course, an exercise of citizenship: it is something that citizens in fact do, but does not fall within the role of citizen. 'Convicted offender' is, however, on this view a distinct civic role: a convicted offender is still unqualifiedly a citizen, who has acquired a new set of rights and duties - most obviously, the duty to undertake his punishment (and it is important to notice that most punishments are actively undertaken, not merely passively suffered); but also the rights to both formal and substantive rehabilitation (and the rights to decent and respectful treatment that all citizens have). On this view, we should not see those who commit crimes as enemies, or outsiders, or 'other'; we must not exclude them, or think that they have excluded themselves, from the civic realm. We see them still as our fellows in the political community: fellows with whom we must engage, though the terms of that engagement must be modulated in the light of their crime; fellows who must have their voice as citizens in the conduct of our collective business - in the res publica.

The former, exclusionary, view is certainly tempting, especially if we do not think deeply about the nature of our social existence, or about what it is to be a community of citizens; it is perhaps more tempting insofar as we see citizenship on the model of a contract: if we are bound to each other only by the terms of a social contract, if citizenship is a matter of signing up to (or being deemed to have implicitly signed up to) that contract, it may be easy to think that one who violates the fundamental terms of the contract ceases to be a party to it. But the latter, inclusionary view is surely more plausible as an ideal to which we should aspire: if we ask ourselves honestly (an honesty that includes a recognition of our own fallibilities, and of our complicity in the maintenance of the conditions of disadvantage from which crime often flows) what we owe to each other as citizens, we must surely answer that we owe a respect and concern that is not thus contingent on non-criminal conduct. There are, of course, good pragmatic reasons for this: since those who serve prison terms normally return to the ordinary civic world after completing their sentences, we must do what we can to assist that return, so that we can again live with them in civic peace; but to the extent that punishment treats the person punished as someone who has lost his civic status, his rehabilitation is made harder. The primary reasons, however, are moral, to do with the political morality by which we are to structure our civic lives, and with how we can see each other as radically imperfect, fallible fellow members of a polity. Punishment, including imprisonment, should not be a way of excluding those punished from fellowship: it should precisely be a way in which we still try to engage with them as fellow citizens. But to deny them the right to vote is to deny a central aspect of that fellowship.

Is this to say that the right to vote is, as a central aspect of citizenship, so fundamental a human right that it must never be removed; that the European Court of 
Human Rights should not allow individual states the leeway that it now allows them to impose selective bars on voting for prisoners? Not quite - for two reasons.

First, it is not to say that citizenship must be wholly unconditional: that there is no crime, no criminal career, that constitutes such a radical denial of fellowship that we should say that it renders continued membership of the polity impossible. But if there are such crimes, they are rare: the vast majority of crimes do not render their perpetrators ineligible for the status of citizen, and thus should not exclude them from voting. This is true even of crimes, such as electoral fraud, that attack the democratic process: if voting was a privilege, that privilege might properly be lost if misused; but since it is a basic civic right (and responsibility), it should not be so easy to lose.

Second, it is not to say that the ECtHR should closely police the decisions of individual states about whether and under what conditions to deny prisoners the right to vote. We face here a familiar kind of dilemma. On the one hand, if this is, as I have argued, a matter of fundamental democratic rights, it seems appropriate that the ECtHR should set very narrow limits on the ways in which, or the conditions under which, that right may be suspended or limited. ${ }^{4}$ But on the other hand, questions about the extent and conditionality of the right to vote are in the end questions about how a democratic polity should understand and define itself, which must be a matter for public deliberation by its own members: although that deliberation should be constrained by respect for human rights that transcend the domestic sphere of the nation state, it requires as wide as possible a margin of appreciation. All I would argue here, however, is that as a matter of human rights, and therefore as something that the ECtHR should declare, there should be a very strong presumption that all citizens, including those serving prison terms, have the right to vote; if that right is to be withdrawn from any prisoners, this should be done only under narrowly defined circumstances, and for clearly articulated reasons that explain why the commission of the specified kind(s) of crime renders the offender ineligible to discharge this central civic responsibility. 